\title{
The effect of pratidina (daily) practice and ekahantara (alternate) practice of nasya with anutaila in chronic sinusitis - A comparative clinical trial
}

\author{
Swathi Tikale', Binitha $\mathbf{A}^{2, *}$ \\ ${ }^{1}$ PG Scholar, ${ }^{2}$ Associate Professor, Dept. of Panchakarma, Kerala University of Health Sciences, Kerala, India \\ *Corresponding Author: Binitha A \\ Email: drbinithaunni@gmail.com
}

\begin{abstract}
Nasya is the panchakarma to eliminate morbid doshas in head and neck. Vagbhatacharya opines that except for Vatika clinical conditions Nasya should be done for 7a days but as ekahanthara (alternate) that is with a gap of one day in between. As no previous studies were available on the efficacy and safety of ekahantara nasya, a comparative clinical study was conducted with anutaila in chronic sinusitis. 20 participants were divided by convenience sampling into group A (pratidina nasya) and group B (ekahantara nasya). The assessment was done by Scoring of symptoms, Haematological evaluation, Rhino sinusitis disability index, Event evaluation scale and Nasya samyak lakshana.

Significant reduction in symptoms score was seen in both group A $(\mathrm{p}<0.01)$ and group B $(\mathrm{p}<0.001)$. The samyak yoga score was $82 \%$ in group A while in group B it was $95 \%$. Asmyak yoga score in group A was $18 \%$ and $5 \%$ in group B and the difference was statistically significant $(\mathrm{p}<0.05)$. Hence the present clinical trial concludes that the ekahantara practice of nasya with Anutaila was more safe and effective compared to pratidina practice of nasya in chronic sinusitis.
\end{abstract}

Keywords: Ekahantara nasya, Pratidina nasya, Chronic sinusitis, Anutaila.

\section{Introduction}

Among the Panchakarma (five biopurificatory procedures), Nasya (Errhine therapy) is said to be effective in curing diseases of Urdhvajatru (supraclavicular region). It is practically more feasible and economic compared to other panchakarma procedures, even at outpatient department and widely practiced with high degree of clinical success. A lot of disparity exists in routine practice regarding the dose and procedure of Nasya. Vaghbhata opines that nasya can be done in morning and evening for 7 days in vaata predominant conditions like sirasoola, hidhma, apatanaka, manyasthambha and swarabhramsa. But in all other conditions nasya may be done on alternate days for 7 days (ekahanthara). ${ }^{1}$ Thus it will take 13 days to finish one course of nasya. Nasya is routinely practiced with sneha because of its feasibility, availability and inherent kaphahara property. Anutaila was selected for the present study considering its trodoshahara properties with special action in naasaroga and sirasoola.

Due to the increased environmental pollution and hectic life, rhinitis is a common condition nowadays, and improper management leads to Sinusitis and later it results into chronic sinusitis. The features of the disease Dushta pratisyaya is similar to chronic sinusitis in ayurvedic literature. ${ }^{2}$ This disease is characterized by nasal blockage, nasal discharge, headache, sneezing, heaviness in head, halitosis etc. Dushtapratisyaya is vata kapha pradhana tridoshaja vyadhi. Caraka has mentioned Nasya as the first line of treatment in dushta pratisyaya. So a comparative study was planned on chronic sinusitis with anutaila between pratidina and ekahantara practice of nasya to find out the safety and efficacy.

\section{Objectives}

1. To assess the safety and efficacy of pratidina practice of nasya with Anutaila in the management of chronic sinusitis

2. To assess the safety and effect of ekahanthara practice of nasya with Anutaila in the management of chronic sinusitis

3. To compare the effects of pratidina practice and ekahanthara practice of nasya in the management of chronic sinusitis

\section{Materials and Methods}

Study Design: Comparative clinical trial

Setting: OPD VPSV Ayurveda College Kottakkal, Kerala

Duration of Study: 18 months

Sample Size: Two groups each with 10 participants

Sampling Technique: 20 samples were divided in two equal groups by using convenience sampling.

Ethical Clearance was obtained from the Ethics Committee VPSV Ayurveda College Kottakkal (IEC/ Doc/18/12 dated 28/05/2012)

\section{Diagnostic Criteria ${ }^{3,4}$}

A) Chronicity - 12 weeks or more duration

B) Signs and symptoms:

Two or more of the following:

1. Muco purulent drainage (anterior, posterior or both)

2. Nasal obstruction (congestion)

3. Facial pain-pressure-fullness, or

4. Decreased sense of smell

C) Inflammation finding documented by one or more of the following findings 5

1. Purulent (not clear) mucus or edema in the middle meatus or ethmoid region

2. Polyps in nasal cavity or the middle meatus, and/or 
3. Radiographic imaging showing inflammation of the paranasal sinuses

Inclusion Criteria

1. Participants indicated for nasya

2. Participants between 20- 60 years of age

3. Sex- no discrimination

4. Participants who have given informed consent

\section{Exclusion Criteria}

1. Participants with chronic debilitating infectious diseases

2. Participants with nasal polyp requiring surgical treatment

3. Participants with the poorly controlled HTN, DM

4. Pregnant/ lactating woman

Table: 1 Details of materials and intervention

\begin{tabular}{|l|c|c|}
\hline \multicolumn{1}{|c|}{ Particulars } & Group A & Group B \\
\hline Sample size & 10 & 10 \\
\hline Drug & Anutaila & Anutaila \\
\hline Dose and procedure & $\begin{array}{c}\text { 4ml (8bindu) in 2 instillations in } \\
\text { each nostril in morning }\end{array}$ & $\begin{array}{c}\text { 4ml (8bindu) in 2 instillations in each nostril in } \\
\text { morning }\end{array}$ \\
\hline Duration of treatment & Max.7 days continuously & Max.7 days alternately (total 13 days) \\
\hline Follow up period & 30 days & 30 days \\
\hline
\end{tabular}

Kottakkal (GMP certified company), Batch No: 161968, Mfg date: August 2012

\section{Assessment}

1. Assessment was done before the treatment and on $8^{\text {th }}$ day after treatment and after follow up period for chronic sinusitis.

2. Assessment of samyak yoga and asamyak yoga of nasya was done on each day of nasya.

\section{Assessment criteria}

1. Scoring of the symptoms

\section{Data analysis}

A detailed Case Record Form (CRF) was used to collect the data. The clinical symptoms, subjective parameters and laboratory parameters were tabulated and subjected to statistical analysis manually with the help of excel sheet.

\section{Observation and Analysis}

Table 2: Effect of therapy on haematological values

\section{Group A}

\begin{tabular}{|l|c|c|c|c|c|c|c|}
\hline Haematological values & Mean BT & Mean AT & MD & \% & SD & t & P \\
\hline Total blood count & 9750 & 9530 & 580 & 5.94 & 633.89 & 0.818 & $>0.05$ \\
\hline Polymorph & 50.5 & 49.9 & 0.6 & 1.1 & 633.85 & 0.823 & $>0.05$ \\
\hline Eosinophil & 3.1 & 4 & -0.9 & 29 & 1.56 & 0.152 & $>0.05$ \\
\hline Lymphocyte & 45 & 44.9 & 0.1 & 0.22 & 5.1 & 0.039 & $>0.05$ \\
\hline ESR & 14.6 & 12 & 2.6 & 17.8 & 3.94 & 2.081 & $>0.05$ \\
\hline $\mathrm{Hb}$ & 12.7 & 12.9 & -0.2 & 3.53 & 0.38 & 1.712 & $>0.05$ \\
\hline
\end{tabular}

\section{Group B}

\begin{tabular}{|l|c|c|c|c|c|c|c|}
\hline $\begin{array}{c}\text { Haematological } \\
\text { values }\end{array}$ & $\begin{array}{c}\text { Mean } \\
\text { BT }\end{array}$ & Mean AT & MD & \% & SD & t & p \\
\hline Total blood count & 9440 & 9050 & 650 & 6.88 & 811.3 & 1.25 & $>0.05$ \\
\hline Polymorph & 50.5 & 49 & 0.5 & 0.91 & 811.3 & 1.25 & $>0.05$ \\
\hline Eosinophil & 4.9 & 3.9 & 1 & 20.4 & 0.84 & 2.37 & $<0.05$ \\
\hline Lymphocyte & 40.3 & 39.1 & 1.2 & 2.97 & 6.21 & 0.46 & $>0.05$ \\
\hline ESR & 14.3 & 11.3 & 3 & 20.9 & 5.81 & 1.40 & $>0.05$ \\
\hline Hb & 12.6 & 13.17 & -0.55 & 4.32 & 0.24 & 4.07 & $<0.05$ \\
\hline
\end{tabular}

On analysing the effect of treatment on mean total count using paired t-test, the result was insignificant statistically ( $p>0.05)$ in both the groups. Similarly, the effect on Polymorph $(p>0.05)$ and on ESR $(p>0.05)$ was insignificant. However the effect on Eosinophil was significant $(\mathrm{p}<0.05)$ in group $\mathrm{B}$, with a reduction of $28.57 \%$ and effect on $\mathrm{Hb}$ was found to be significant $(\mathrm{p}<0.05)$ with the improvement of $4.6 \%$ in the ekahantara group (Gp B)
Effect of Therapy on Rhino Sinusitis Disability Index: The effect of therapy in both the groups were analysed using paired t-test and was found statistically highly significant at p $<0.001$. Nasya with Anutaila was effective in reducing the Rhino sinusitis disability questionnaire scores of both the groups. 
Table: 2 Comparison of the effect of treatment on Rhino sinuitis disability index in both groups

\begin{tabular}{|c|c|c|c|}
\hline \multicolumn{1}{|c|}{ Group } & Mean AT & t & P \\
\hline A & 7.2 & \multirow{2}{*}{1.735} & $>0.05$ \\
\cline { 1 - 2 } B & 9.3 & & \\
\hline
\end{tabular}

Effect of Therapy on Clinical Symptoms of the Diseases: The effect of therapy on clinical symptoms was assessed comparing the mean scores, before, after the treatment and after a follow up period of 30 days in both the groups. The symptoms analysed were naasasrava, kshavthu, naasavarodha, sirasoola, and sirogourava, kaasa, ghranaviplava, swarabedha aruchi, post nasal drip and mukhadourgandhya.

Table 3: Effect of treatment on Group A

\begin{tabular}{|l|c|c|c|c|c|c|c|}
\hline \multicolumn{1}{|c|}{ Clinical symptoms } & Mean BT & Mean AT & MD & \% & SD & t & p \\
\hline Nasasrava & 0.8 & 0.1 & 0.7 & 87.5 & 1.15 & 1.90 & $>0.05$ \\
\hline Kshvathu & 1.9 & 0.6 & 1.3 & 68.4 & 1.70 & 3.15 & $<0.01$ \\
\hline Nasavrodha & 3 & 0.9 & 2.1 & 70 & 0.87 & 7.58 & $<0.001$ \\
\hline Ghranaviplava & 2.2 & 0.8 & 1.4 & 63.3 & 1.34 & 3.74 & $<0.01$ \\
\hline Post nasal drip & 2.8 & 0.6 & 2.2 & 78.5 & 0.91 & 7.50 & $<0.01$ \\
\hline Kasa & 1.4 & 0.3 & 1.1 & 78.5 & 1.59 & 2.18 & $>0.05$ \\
\hline Aruchi & 0.7 & 0.3 & 0.4 & 57.1 & 0.69 & 1.80 & $>0.05$ \\
\hline R.D.I & 34.7 & 7.2 & 27.5 & 78.6 & 7.94 & 11.3 & $<0.001$ \\
\hline
\end{tabular}

Table 4: Effect of treatment on Group B

\begin{tabular}{|l|c|c|c|c|c|c|c|}
\hline \multicolumn{1}{|c|}{ Clinical symptoms } & Mean BT & Mean AT & MD & \% & SD & t & p \\
\hline Nasasrava & 1.6 & 0.4 & 1.2 & 75 & 1.13 & 3.34 & $<0.01$ \\
\hline Kshvathu & 2.7 & 0.5 & 2.2 & 81.4 & 1.05 & 5.65 & $<0.001$ \\
\hline Nasavrodha & 3 & 0.8 & 2.2 & 73.3 & 0.42 & 16.4 & $<0.001$ \\
\hline Ghranaviplava & 1.5 & 0.4 & 1.1 & 73.3 & 1.10 & 3.16 & $<0.01$ \\
\hline Post nasal drip & 1.8 & 0.3 & 1.5 & 83.3 & 1.17 & 4.02 & $<0.001$ \\
\hline Kasa & 1.7 & 0.3 & 1.4 & 82.3 & 1.34 & 3.27 & $<0.01$ \\
\hline Aruchi & 0.5 & 0 & 0.5 & 100 & 0.84 & 1.86 & $>0.05$ \\
\hline R.D.I & 33.4 & 6.2 & 27.2 & 81.43 & 5.19 & 14.6 & $<0.001$ \\
\hline
\end{tabular}

Table 5: Comparison of effect of treatment

\begin{tabular}{|l|c|c|c|c|}
\hline Clinical symptoms & $\begin{array}{c}\text { Group A } \\
\text { Mean A T }\end{array}$ & $\begin{array}{c}\text { Group B } \\
\text { Mean AT }\end{array}$ & t & p \\
\hline Kshvathu & 0.51 & 0.52 & 0.42 & $>0.05$ \\
\hline Nasavrodha & 0.7 & 0.4 & 0.37 & $>0.05$ \\
\hline Ghranaviplava & 0.6 & 0.4 & 0.53 & $>0.05$ \\
\hline Post nasal drip & 0.6 & 0.3 & 1.11 & $>0.05$ \\
\hline R.D.I & 7.2 & 9.3 & 1.73 & $>0.05$ \\
\hline
\end{tabular}

\section{Overall effect of clinical symptoms}

\section{Graph 1}

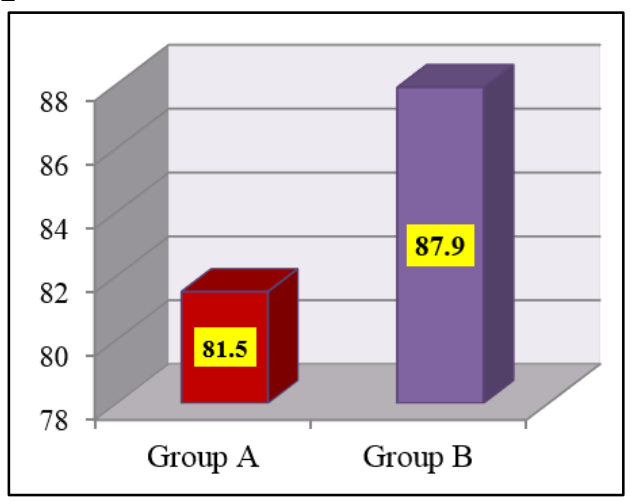

In both groups effect of therapy was analysed using paired $t$ test and a statistical significance of $p<0.01$ was obtained in group B and statistically insignificant $p>0.05$ for group A, for nasasrava, kasa and aruchi. It shows that nasya with Anutaila gave a significant relief for these symptoms in group B and for group A there was no significant relief.

When the scores before and after the treatment were compared, statistical significance of $p<0.001$ was obtained for all clinical symptoms except kshavathu, nasaavarodha, ghranaviplava, aruchi, Post nasal drip and Rhinosinusitis Disability Index.

Repeated measures of ANOVA test was used to compare the effect of treatment in group A, before treatment, after treatment and after the follow up. Significance $\mathrm{p}<0.001$ was obtained for shirasoola, shirogaurava, kasa and mukhadaurgandhya. Before 
treatment and after the follow up, significance was $\mathrm{p}<0.01$ and after the treatment and after the follow up, the result was insignificant with $\mathrm{p}>0.05$. Therefore it was concluded that the effect of treatment was sustained up to the follow up period.

Table 4: Comparison of mean Samyak yoga between group A and group B

\begin{tabular}{|l|c|c|c|c|}
\hline S. No & Symptoms & Group A mean & Group B mean & M.D (B-A) \\
\hline 1 & Sroto sudhi & 3.64 & 5.35 & 1.71 \\
\hline 2 & Vikaropasama & 6.5 & 7.35 & 0.85 \\
\hline 3 & Indria chitta prasada & 3.42 & 5.14 & 1.72 \\
\hline 4 & Swara prasada & 3.21 & 3.35 & 0.14 \\
\hline 5 & Varna prasada & 0 & 0 & 0 \\
\hline 6 & Sukhaswapna prabodha & 2.85 & 3.42 & 0.57 \\
\hline 7 & Sukhochvaasanisvasa & 3.353 & 5.78 & -0.43 \\
\hline 8 & Akshapatavam & 3.14 & 2.71 & 0.42 \\
\hline 9 & Akshi laghuta & 5 & 5.42 & 0.57 \\
\hline 10 & Vaktra sudhi & 4.14 & 4.71 & -0.79 \\
\hline 11 & Urah laghuta & 4.14 & 3.35 & 1 \\
\hline 12 & Kshavathu & 2.7 & 3.71 & $0.74(6.21 \%)$ \\
\hline
\end{tabular}

\section{Observation on Nasya Samyak Yoga}

The samyak yoga lakshana of nasya were analysed with respect to 12 lakshanas compiled from classics. In both groups, the samyak lakshana had no significant difference statistically. The score was higher in group A indicating a better and sustained effect. Samyak yoga was assessed daily and 24 hours after each day's nasya. Mean samyak yoga score in group A was 3.83 out of 12. On first day mean score was 0.41 and became 5.37 on the last day of nasya. Highest score 7.5 was observed on $5^{\text {th }}$ day. Mean score of swaraprasada and akshapatavam gradually increased from $1^{\text {st }}$ to $7^{\text {th }}$ day in group A. For rest of the symptoms the mean score showed sudden decrease on $6^{\text {th }}$ and $7^{\text {th }}$ day in group A. Among all symptoms vaktrasudhi was observed with more score. Mean samyak yoga in group B was 4.57 out of 12 . On first day mean score was 0.751 and became 6.2 on the last day of nasya. Highest score was observed on $9^{\text {th }}$ day.

\section{Graph 2}

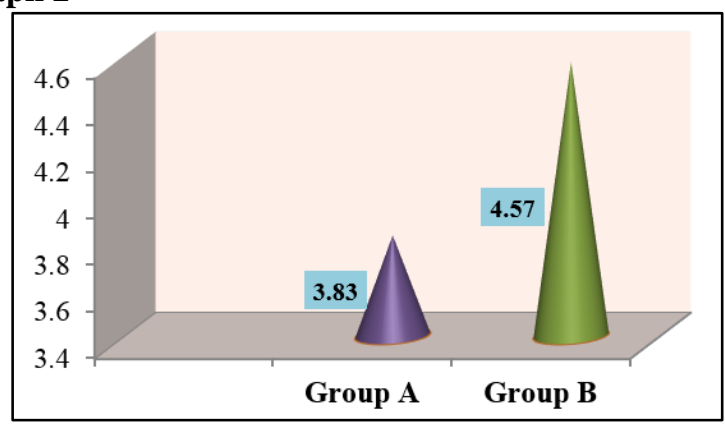

Table 5: Mean score - asamyak lakshana

\begin{tabular}{|l|l|c|c|c|}
\hline No. & Symptoms & $\begin{array}{c}\text { Group A } \\
\text { Mean }\end{array}$ & $\begin{array}{c}\text { Group B } \\
\text { Mean }\end{array}$ & $\begin{array}{c}\text { M.D } \\
\text { (B-A) }\end{array}$ \\
\hline 1 & Nasakleda & 2.57 & 1.78 & 0.79 \\
\hline 2 & Daha & 2 & 0.57 & 1.43 \\
\hline 3 & Shiroarti & 1.28 & 0 & 1.28 \\
\hline 4 & Kshmatva & 1.71 & 0.14 & 1.42 \\
\hline \multicolumn{2}{|r|}{ Total score } & $1.82(7.9 \%)$ & $0.37(2.61 \%)$ & $1.45(5.3 \%)$ \\
\hline
\end{tabular}

\section{Graph 3}

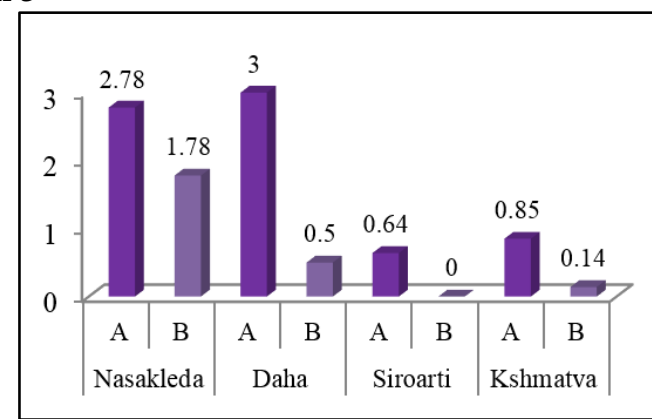

Total 23 symptoms were assessed for Nasya asamyak yoga. It included symptoms of Heena yoga, atiyoga and Vyaapat. The mean Asamyak yoga score in group A was $0.85(3.6 \%)$ out of 23.

On the first day of Nasya the mean Asamyak yoga score was $1.3(5.6 \%)$ which became $1.4(6.2 \%)$ on the last day. The total mean score was maintained same throughout the course of Nasya. In pratidina nasya mean score was 2 times more than that of ekahantara nasya. There was difference of $1.3(5.7 \%)$ between two groups as kandu, shirogaurava, guruta was not observed in pratidina nasya group during 
the course of nasya. As all the symptoms were absent in pratidina nasya, heena yoga of S'odhana was absent. Only galoplepa was present during first two days of nasya. As this is a subjective feeling, no heena yoga lakshanas can be justified. Among the Asamyak yoga symptoms nasakleda, daha and kshmatva were observed in the pratidina group. As Nasya is a S'odhana procedure and all nasya causes s'irovirecana irrespective of br'mhana or s'amana action. Atiyoga of S'odhana may manifest as nasakleda, daha and kshmatva symptoms. Thus it can be stated that pratidina practice of nasya caused Ati yoga of S'odhana.

On comparison it was found that nasakleda, daha score were present more in group A compared to group B. In group A total Asamyak yoga score was 0.857 (3.69\%) and in group B total Asamyak yoga score was $0.23(1 \%)$. There was difference of $0.625(2.71 \%)$ between two groups. On comparison it is shown that mean difference in Asamyak yoga score between group A and group B is 0.625 which are statistically significant at $<0.05$ level.

\section{Discussion}

Sukhswapnaprabodha, swaraprasada, akshilaghuta, urahlaghuta \& kshvathu have achieved maximum score in ekahantara practice of nasya which indicates that kapha s'odhana was more in ekahantara practice of nasya.

Comparative illustration of Samyak Yoga from 1st day to 7th day

\section{Graph 4}

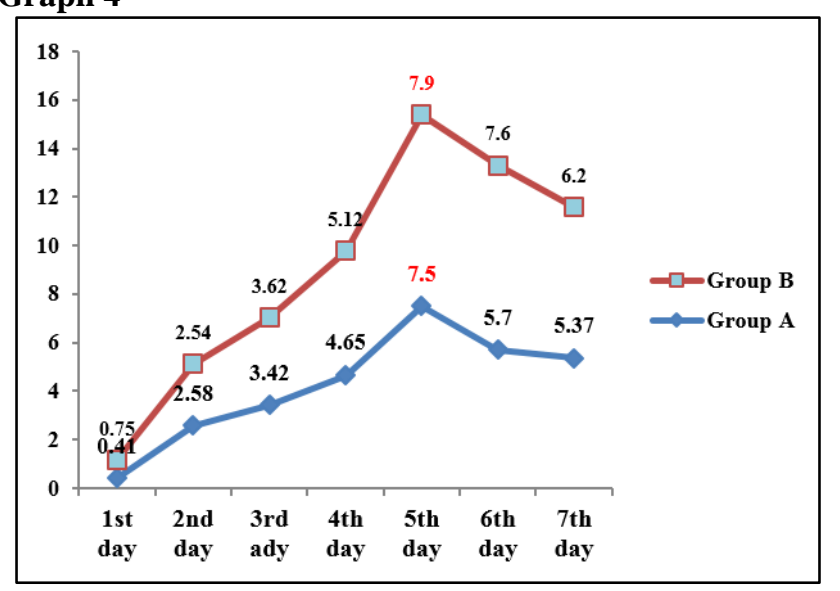

On comparison it was found that srotoshudhi in group A on 1 st day was $4.1 \%$ and which became $41 \%$ on last day. In group B, $29.1 \%$ first day score changed to $66.6 \%$. In chronic sinusitis, patients will have nasal obstruction which has been assessed in terms of srotoshudhi as samyak lakshana. The more score in ekahantara nasya proved that reduction in nasal obstruction by ekahantara nasya was more. Because of more kaphas' odhana obtained in ekahantara nasya compared to pratidina nasya which ultimately resulted in srotoshudhi symptom. Similarly on comparison it was found that sukhocchnisvasa in group A on $1^{\text {st }}$ day was $8.3 \%$ and which became $41.6 \%$ on last day. In group B, $37 \%$ first day score changed to $70.8 \%$. The more score in ekahantara nasya proved that reduction in swasavrodha by ekahantara nasya was more. This symptom is dependent on the srotoshudhi. Nature of kapha s'odhana was more in ekahantara nasya which resulted in achievement of srotoshudhi \& sukhocchavaasa symptoms.

Swaraprasada in group A on $4^{\text {th }}$ day was $8.3 \%$ and which became $66.6 \%$ on last day. In group B, $12.5 \%$ third day score changed to $70.8 \%$. For Akshapatvam in group A on $3^{\text {th }}$ day was $4.1 \%$ and which became $66.6 \%$ on the last day. In group B, $12.5 \%$ fifth day score changed to $79.1 \%$. In chronic sinusitis, patients will have change in voice as symptom which has been assessed in terms of swaraprasada as samyak lakshana. ${ }^{10}$ Because of enhanced kapha s'odhana in ekahantara nasya, more reduction of avarana of vata by kapha $\&$ hence, swarabheda score was obtained in more percentage in ekahantara nasya compared to pratidina nasya.

Vikaropsama in group A on $1^{\text {st }}$ day was $16.6 \%$ and which became $60 \%$ on last day. In group B, $16.6 \%$ first day score changed to $83.3 \%$. For Indriya cittaprasada in group A on $3^{\text {rd }}$ day was $8.3 \%$ and which became $37.5 \%$ on the last day. In group B $20.8 \%$ third day score changed to $58.7 \%$. The more score in ekahantara nasya proved that reduction in clinical symptoms of disease by ekahantara nasya was more as kapha nirharna was obtained significantly more in ekahantara nasya.

Sukhaswapnaprabodhana in group $\mathrm{A}$ on $2^{\text {nd }}$ day was $8.3 \%$, which became $37.5 \%$ on fourth day and later became $25 \%$. In group B, $20.8 \%$ third day score changed to $58.3 \%$ on eleventh day and on last day it was changed to $54.1 \%$. 'Disturbances in night sleep' due to nasal obstruction, cough $\&$ headache was present with the entire participants. Due to reduction in nasal obstruction, cough \& headache Sukhawapnaprabodhana was observed in ekahantara nasya attained by srotoshudhi, sukhocchanisvasa \& vikaropashma symptoms.

Akshilaghuta in group A on $2^{\text {nd }}$ day was $29.9 \%$, which became $75 \%$ on fifth day \& which became $62.5 \%$ on the last day of nasya. In group B $16.6 \%$ first day score changed to $79.1 \%$. Urolaghuta in group A on $3^{\text {rd }}$ day was $4.1 \%$, which became $75.1 \%$ on the last day. In group B $16.6 \%$ first day score changed to $75 \%$. In chronic sinusitis, patients will have heaviness in chest and head as symptom which has been assessed in terms of akshilaghuta \& urolaghuta as samyak lakshana. Kapha is mainly responsible for producing guruta. Upto fifth day there was proper expulsion of kapha which resulted in samyak lakshna as akshilaghuta $\&$ urolaghuta but beyond fifth day kapha s'odhana was less. In group B akshilaghuta \& urolaghuta score gradually increased upto last day of nasya which indicated there was negligible atiyoga lakshana on last days of nasya. As it was op level study, patients had to travel daily for seven days and more exposed to environmental aggravating factors. These factors resulted in patient's psychological as well as general health condition. Hence, many asamyak lakshanas were also obtained in pratidina nasya.

There was continous expulsion of kapha in pratidina nasya and on alternate days in ekahantara nasya. So the accumulated kapha during the rest day was expelled out the 
next day in ekahantara nasya. At the same time patient was not exposed to frequent aggravating factors like environmental, physical exertion by travelling etc. Hence there was attainment of more samyak lakshanas and negligible asamyak lakshanas in ekahantara nasya.

There was very higher percentage of Naasaakleda in group A compared to group B from the first day onwards. The score on last day was 0 in group B. 50\% participants were having the history of deviated nasal septum, hypertrophied turbinate in $100 \%$ and congested nasal mucosa in $80 \%$ of participants. It was observed that due to deviation, nasal volume reduced on deviated side and not enough capacity to accommodate more amount of medicine leading to nasal congestion or naasaakleda. In pratidina group participants vatakopa was observed because of daily excessive kapha sodhana and also these participants were more exposed to environmental factors which have role in development of transient nasal obstruction. But mean score showed that the severity of these symptoms were within the manageable limits and it did not affect the safety of the nasyakarma.

There was very higher percentage of daha in group A compared to group B from the first day onwards. The score on last day was 0 in both the groups. Anutaila possess sheeta veerya and ushna veerya drugs. Dose was also high which could also be contributory. Nasya acts by irritating nasal mucosa irrespective of the drug. In pratidina group nasal mucosa was continuously exposed to drug. This continuous irritation of mucosa led to more daha symptom score in pratidina group compared to ekahantara group. Irritaing nature of nasya assessed by the objective parameter, eosinophil count. In pratidina group after treatment the count increased where as in ekahantara nasya it decreased. The irritation of nasal mucosa healed on resting day and did not lead to inflammation in ekahantara nasya.

There was very higher percentage of shiroarti \& kshmatva in group A compared to group B on last three days of nasya. The mean score was more on last days of nasya in group A whereas it was 0 on last days in group B for kshmatva. shiroarti was not observed in group B. Shiroarti and kshmatva mainly developed by vaatakopa. In pratidina nasya daily kapha s'odhana led to vaatakopa mainly during last days of nasya. Physical exertion and travelling also contributed for the vitiation of vaata. In ekahantara nasya there was proper expulsion of accumulated kapha which caused minimal vaatakopa and minimum mean score of kshmatva was observed on last three days of nasya.

\section{Conclusion}

The main objective of the study was to compare the effect, safety and attainment of samyak lakshana of marsa nasya with the routinely practiced (pratidina) continuous days and (ekahanthara) alternate days of nasya in chronic sinusitis. Chronic sinusitis is an urdhvajatrugata vikara and has vaatakapha predominance and the disease can be seen in paralance with ayurveda literature as Dushta pratisyaya.
Anutaila being ushna in veerya and tridoshahara property helps in breaking the samprapti of chronic sinusitis. The conclusion drawn on the basis of this clinical study conducted in 20 participants of chronic sinusitis are as follows:

1. The significant difference obtained for asamyak lakshana as daaha in pratidina nasya compared to ekahantara nasya $\mathrm{p}<0.05$, but within manageable limit.

2. Pratidina practice of nasya with Anutaila in chronic sinusitis is safe and effective.

3. Ekahantara practice of nasya with Anutaila in chronic sinusitis is safe and effective.

4. On comparing the effect of treatment in pratidina and ekahantara group, more result was obtained in ekahantara group.

5. The present study recommends ekahantara practice of nasya with Anutaila in chronic sinusitis in OPD basis.

\section{Limitations and Recommendations}

1. The dose, number of instillation and number of days of Nasya was predetermined.

2. Rhinosinusitis disability index questionnaire could have been assessed daily.

3. No objective parameter is used in the study.

4. Highly sensitive tools are not available to assess Samyak and Asamyak yoga of nasya.

5. Effects of climate variation couldn't be avoided, as in rainy and cloudy days nasya is contraindicated.

6. Sample size was small.

\section{Recommendations}

1. Objective parameters can be used to make study more scientific and reliable such as CT scan etc.

2. Validation and revalidation of samyak and asamyak yoga proforma can be done.

3. Asamyak yoga should be critically analyzed according to drug, dose \& procedure.

4. Study can be done in larger sample.

5. Study can be done in IPD level to avoid effect of external environmental factors.

6. Shamana medicine after nasya can be given for better result after treatment.

7. Nasya can be done upto achievement of samyak lakshanas irrespective of days.

Conflict of Interest: Nil.

\section{References}

1. Vagbhata. Ashtanga Hridaya - Sarvanga Sundari Comm. Arunadatta, Choukhambha Krishna Das Academy, Varanasi, 2000, Sutra Sthana 20/16

2. Vagbhata. Ashtanga Hridaya - Sarvanga Sundari Comm. Arunadatta, Choukhambha Krishna Das Academy, Varanasi, 2000, Sutra Sthana 20/33.

3. Prevalence of the chronic sinusitis diagnosis in Olmsted country, Minnesota shashy Moore EJ, Weaver A Dept. of otolaryngology, Mayo Clinic, Rochester MN 55905, USA

4. Otolaryngology - Head and Neck surgery (2007) 137, S1-S31 GUIDELINES Clinical Practice guideline: Adult Sinusitis. 
5. P. L. Dhingra. Diseases of Ear Nose and Throat, Published by Churchill Livingstone PVT Ltd New Delhi, 2nd Edition 1998.

6. Bhattacharyya N. Clinical and symptom criteria for the accurate diagnosis of chronic rhinosinusitis. Laryngoscope 2006; 116(Suppl110):1-22

7. Bhattacharyya T, Piccirillo J, Wippold FN. Relationship between patient-based descriptions of sinusitis and paranasal sinus computed tomographic findings. Arch Otolaryngol 1997; 123:1189-1192.

8. Benninger MS, Ferguson BJ, Hadley JA. Adult chronic rhinosinusitis definitions, diagnosis, epidemiology, and pathophysiology. Otolaryngol Head Neck Surg 2003;129(Suppl):S1-S32

9. Hwang PH, Irwin SB, Griest SE. Radiological correlates of Symptom-based diagnostic criteria for chronic rhinosinusitis. Otolaryngol Head Neck Surg 2003;128:489-496.
10. Stankiewicz JA, Chow JM. Nasal endoscopyand the definition and diagnosis of chronic rhinosinusitis. Otolaryngol Head Neck Surg 2002;126:623-627.

How to cite this article: Tikale S, Binitha A. The effect of pratidina (daily) practice and ekahantara (alternate) practice of nasya with anutaila in chronic sinusitis - A comparative clinical trial. J Prev Med Holistic Health. 2018;4(2):61-67. 